\title{
Structuring Corporate Boards: Some Facts and Determinants from the Macedonian Setting
}

\author{
Bobek Suklev ${ }^{1}$, Stojan Debarliev² ${ }^{2}$ Ljubomir Drakulevski ${ }^{3}$
}

Submitted: 29.02.2020. Accepted: 8.05.2020

\section{Abstract}

Purpose: Knowing the factors that might affect board structure is an important step in understanding boards and their role in corporate governance. This research aims to examine the effect of firm characteristics closely related to corporate governance mechanisms, such as the model of corporate governance, shareholder capital concentration, and stock exchange listing on board structure variables (size, independence, and gender diversity).

Methodology: The sample of this study stems from large Macedonian joint-stock companies. We run a hierarchical linear regression of board characteristics on common demographic firm characteristics as control variables and contextual firm characteristics related to corporate governance mechanisms as independent variables.

Findings: Joint-stock companies in the Republic of North Macedonia have relatively small boards, which provide no positive effects that would originate from the larger number of board members. Moreover, the number of outside independent members is small, insufficient to influence the boards with greater objectivity, independence, and quality. Larger companies with a one-tier model have statistically significant larger corporate boards and a larger number of independent directors.

Implications: The best corporate governance practices worldwide must be used as a basis for future improvements of corporate governance in joint-stock companies in developing economies.

Keywords: corporate governance, firm characteristics, board size, board independence, board diversity

JEL: G34

\footnotetext{
1 Ss. Cyril and Methodius University in Skopje, Faculty of Economics-Skopje, Skopje 1000, North Macedonia; e-mail: bobek.suklev@eccf. ukim.edu.mk.

2 Corresponding author; Ss. Cyril and Methodius University in Skopje, Faculty of Economics-Skopje, Skopje 1000, North Macedonia; e-mail: stojan.debarliev@eccf.ukim.edu.mk; https://orcid.org/0000-0003-4557-8204.

3 Ss. Cyril and Methodius University in Skopje, Faculty of Economics-Skopje, Skopje 1000, North Macedonia; e-mail: ljubomir.drakulevski@ eccf.ukim.edu.mk.
} 


\section{Introduction}

The theory of and research in corporate governance provides evidence that the ability of boards of directors to perform their service, strategy, and control roles mostly depends on board structure characteristics, such as size, composition, diversity, committees, and meetings (Pearce and Zahra, 1992). Nonetheless, scholarship offers little insight into the effects of different firm characteristics on the board structure characteristics, not to mention moderated impacts of the latter on the relationship between board structure and performance. Hence, one of the main constraints of many studies is their nearly universal focus on the direct relationship between corporate governance mechanisms and firms' financial performance, which undoubtedly results from limitations in researcher abilities to uncover optimal governance mechanisms and configurations (Daily and Dalton, 2003).

However, the review of the few studies that investigated the direct link between firm characteristics and board structure characteristics reveals possible determinants of effective corporate boards, such as general firm characteristics (ownership, industry; Ferreira and Kirchmaier, 2013), the firm's external environment regulation, legal and operating environment (Pearce and Zahra, 1992; Hermalin and Weisbach, 1998; Boone et al., 2007), corporate strategy (Hermalin and Weisbach, 1998), corporate restructurings (Ning et al., 2007), the scope and complexity of the firm's operations (Boone et al., 2007), the past financial performance of the company (Pearce and Zahra, 1992; Hermalin and Weisbach, 1998), other corporate board's characteristics (Hermalin and Weisbach 1998; Ning et al., 2007), country effects (Ferreira and Kirchmaier, 2013), and national institutional characteristics (Guest et al., 2008). This review elucidates that the research in this field mainly focuses on general firm characteristics, specific strategic, and organizational characteristics, but also characteristics of external environment. Hence, the literature and empirical research lack studies that more closely investigate possible determinants of effective corporate board structure in relation to corporate governance mechanisms.

Furthermore, Guest et al. (2008) argue that the relationship between board size and performance may differ not just by firm-specific characteristics but also by national institutional characteristics. The mixed results about the relationship between board characteristics and firm performance appear because some studies omitted such variables as managerial behavior in the market and differences in institutional factors (Alqatan et al., 2019). While much of the corporate governance debate and research activity focused on the USA, there is a growing international literature on corporate governance from other countries (Ferreira and Kirchmaier, 2013). Despite the growing 
international literature and the importance of this topic, there is a lack of research on determinants of corporate board structures in a non-USA context, even more in developing and, particularly, former communist countries. Privatization did not bring anticipated improvements in corporate efficiency. Internal owners prevail in many companies, while external owners do not have voting power to control the companies and to ensure appropriate returns. Capital markets are underdeveloped and do not facilitate the inflow of new capital as intended. The development of corporate governance occurred simultaneously with the processes of privatization and market economy institution building (Dibra et al., 2013). Ferreira and Kirchmaier (2013) emphasize the need for the investigation of former communist countries as to the specific political and economic context and the impact of this dimension on board characteristics, but only as a dummy variable, not examining more thoroughly any specific characteristics and important contextual factors related to corporate governance dimensions.

Our study aims to examine the effect of firm characteristics related more closely to corporate governance mechanisms, such as the model of corporate governance, shareholder capital concentration, and stock exchange listing on board structure variables (size, independence, and gender diversity). In order to isolate the effect of factors that are not in our primary focus - such as company size and industry effect - we add these variables to the model as control variables. Since there are many different firm characteristics possible for investigation, we narrow our focus on the firm characteristics that fill the gap in the literature and the need for the study of more corporate governance-related factors; not to mention the factors that are specific in the context of Republic of North Macedonia as a developing former communist country that experienced transition. Hence, a general research question that arises from the aim of this study is: Do firm characteristics related to corporate governance mechanisms and specific contextual factors affect the board structure characteristics (size, independence, and gender diversity)?

Knowing the factors that might affect board structure is an important step in understanding boards and their role in corporate governance. Besides the possible predictors, this study aims to bring some insights into the corporate board structure characteristics that might facilitate effective corporate governance through the analysis of good corporate governance practices in developed countries. The practical implication lies in the purpose of our study to seek and identify the best practices in effective corporate board structuring and simultaneously propose suggestions for improving the current state of good corporate governance practices. Furthermore, the study should provide valuable findings related to contextual factors typical of the specific Macedonian setting. Summarized findings lead us to the general conclusion that Macedonian joint-stock 
companies are still lagging in several areas of good corporate governance practices, as they require certain improvements in the structuring and functioning of corporate governance.

\section{Literature review}

\section{The Importance of the Board of Directors for Effective Governance}

There are numerous different definitions of corporate governance. Probably, the most cited definition is that by Shleifer and Vishny (1997): "Corporate governance deals with the ways in which suppliers of finance to corporations assure themselves of getting a return on their investment." Moreover, commonly cited definitions are those by the OECD, World Bank, and the Cadbury Report. According to the OECD definition, "Corporate governance involves a set of relationships between a company's management, its board, its shareholders, and other stakeholders" (OECD, 2004). While the Cadbury Report states: "Corporate governance is the system by which companies are directed and controlled" (Cadbury Report, 1992). Finally, World Bank (2014) defines corporate governance as follows: "Corporate governance concerns the relationships among the management, board of directors, controlling shareholders, minority shareholders and other stakeholders."

The first generation of studies in corporate governance examines governance mechanisms, particularly board and ownership structures. This research on corporate governance mechanisms generally concerns two questions. First, do corporate governance mechanisms affect firm performance, typically measured by profitability or relative market value? Second, do these mechanisms affect the particular decisions made by firms, such as management turnover and replacement, investment policy, and reactions to outside offers for control (Denis and McConnell, 2003)?

Although actual evidence yields mixed results about the types of board structure characteristics that facilitate effective corporate governance, they still stress board size and composition as the main determinants of corporate boards' effectiveness. According to the UK's CGC (Corporate Governance Code) (2016), the key features of an effective board of directors primarily relate to board size, board structure, and the separation of CEO and chairman position. In practice, these board structure characteristics are discussed as the most common and frequent contributors to the ability of boards to perform their service, strategy, and control roles, but also to the main predictors of board effectiveness (Pearce and Zahra, 1992; Jensen, 1993; Dalton et al., 1998; Raheja, 2005; Boone et al., 2007; Ning et al., 2007; Coles et al., 2008; Guest, 2008; Ferreira and Kirchmaier, 2013). Furthermore, for these two main characteristics of corporate boards, 
gender is a dimension of diversity that received worldwide attention from scholars and especially regulators. The diversity issue is complex and multi-dimensional, and it encompasses different demographic characteristics, such as gender and racial representation in the board, ethnic affiliation, and nationality (Singh et al., 2008).

Regarding the impact of board size on organizational performance, there are many studies with very different results. From an agency perspective, we may argue that the larger the board, the more likely it is to be vigilant regarding agency problems, simply because a greater number of people will be reviewing its management actions. However, agency theorists recognize that there is an upper limit to boards. Jensen (1993) suggests this limit is around eight directors, as any higher number will interfere with group dynamics and inhibit board performance or the ability of a board to initiate strategic interactions (Goodstein et al., 1994). Moreover, there is a positive association between group cohesion in boardrooms and the effectiveness of boards to deliver positive firm performance (Paniagua et al., 2018).

Furthermore, some studies support the resource dependence theory, as companies see the need for greater links with other organizations. Yermack (1996) suggests an inverted U-shaped relationship between board size and firm performance. The addition of directors adds to the skills mix and performance of board and firm until it reaches a tipping point when the adverse dynamics of a large board outweigh the additional benefits of a greater skills mix. Besides the dominant two theories in this filed - agency theory and resource dependence theory - the Equilibrium Model assumes that the transaction costs of optimizing board structure are relatively low, so that shareholders, directors, and top managers work together to choose the optimal board size to maximize the firm value (e.g., Lehn et al., 2006; Boone et al., 2007; Linck et al., 2008).

Concerning the impact of board composition on firm performance, much of the literature confirms that efficient boards of directors have a larger proportion of outside directors playing a crucial role in monitoring the firm's activities (Paniagua et al., 2018). In this sense, the empirical results show that the presence of independent directors on the board positively affect the level of financial performance (Ahmadi et al., 2018; Alqatan et al., 2019; Kao et al., 2019; Tulung and Ramdani, 2018; Ertimura et al., 2010; Chau and Gray, 2010). For potential investors, the firm's value would rise, and they would perceive that financial and nonfinancial aspects of the firm are better, if outside directors are employed (Ahmadi et al., 2018). According to the UK's CGC (2016, p. 11), "Except for smaller companies, at least half the board, excluding the chairman, should comprise of non-executive directors determined by the board to be independent." In this sense, the independent nonexecutive directors can bring an effective monitoring 
mechanism and reduce negative issues related to the conflict of interest and information asymmetry (Alqatan et al., 2019).

The increased number of women in top management and corporate boards of directors has led to growing literature related to gender diversity. While the research on gender diversity continues to grow, empirical research on boards' gender diversity and corporate performance remains mixed and concentrated in few studies (Ahmadi et al., 2018). Research on Fortune 1000 firms finds that there is a significant and positive relationship associated with the fraction of women on the board and firm performance (Carter et al., 2003). According to resource dependence theory, women on corporate boards are wanted because they can offer a wide base of resources, such as knowledge, legitimacy, prestige, and connections to external sources (Peterson and Philpot, 2007).

\section{Corporate Board Structure Characteristics and Possible Determinants}

As we mentioned in the introduction, the constraints of many studies in this field are their nearly universal focus on the direct association between corporate governance mechanisms such as board structures and organizational effectiveness (Daily and Dalton, 2003). Hence, after the selection of the main board structure characteristics, the second task of the literature review is to seek important and commonly investigated predictors that might affect corporate board structure by reviewing each of the board characteristics.

The knowledge reviewed in the literature, reveals many different probable determinants of effective corporate board structure, which indeed represent different internal and external firm characteristics. Some of the most commonly researched determinants that might affect effective corporate structures are ownership, firm characteristics across industries, regulation, legal and operating environment, business conditions, corporate restructurings, characteristics of surviving and delisted firms, regulated and unregulated companies, firms in financial distress, and bankrupt firms (Ning et al., 2007); characteristics of the firm's external environment, the demands of its strategy, salient contextual factors, and the past financial performance of the company (Pearce and Zahra, 1992); country effects, industry effects, and firm characteristics (Ferreira and Kirchmaier, 2013); national institutional characteristics (Guest et al., 2008); joint forces of the environment, corporate strategy, and past performance (Hermalin and Weisbach, 1998); the scope and complexity of the firm's operations, along with the specific business and information environment in which the firm operates (Boone et al., 2007); negotiation between the CEO and outside directors (Hermalin and Weisbach, 1998). 


\section{Conceptual Development: Research Model Construction}

The next task of our analysis is to develop an empirical model that links the potential predictors to selected corporate board characteristics. Above, we identify two board characteristics - board size and composition (i.e., independence) - as primary determinants of corporate board effectiveness. Furthermore, we add gender diversity to these two main characteristics of the board of directors as a dimension that received worldwide attention from researchers and regulators.

As we clarified in the introduction, what is evident from the literature review is that it mainly focuses on general firm characteristics, specific strategic and organizational characteristics, and some dimensions of external environment (Ning et al., 2007; Pearce and Zahra, 1992; Ferreira and Kirchmaier, 2013; Guest et al., 2008; Hermalin and Weisbach, 1998). Hence, there is a lack of studies that more closely investigate possible determinants of effective corporate board structure related to corporate governance mechanisms. Moreover, despite the growing international literature and the importance of this topic, there is a scarcity of investigations on determinants of corporate board structure in non-USA contexts, even more in developing and, particularly, former communist countries. In this sense, Ferreira and Kirchmaier (2013) emphasize the need for the examination of former communist countries as a specific political and economic context, and for considering the impact of this dimension on board characteristics. However, the authors refer to former communist countries only as a dummy variable, without more thoroughly examining the characteristics and important contextual factors related to corporate governance dimensions.

Since there are many different firm characteristics that might affect corporate board characteristics, we aim to examine those characteristics, i.e. contextual factors specific for the context of the Republic of North Macedonia as a developing former communist country that experienced the transition from communist to capitalist economy. The selected characteristics, particularly concerned with the corporate governance context, are the model of corporate governance, shareholder capital concentration, and stock exchange listing.

\section{Contextual Factors Specific to the Republic of North Macedonia}

\section{Corporate Governance Model}

What is specific for the case of the Republic of North Macedonia is the fact that it is among the few countries in Europe (nine of 28) that offers the option of both one-tier and two-tier corporate board systems, which allow for a choice between the two types 
of corporate board structures (Ferreira et al., 2010). According to Macedonian Company Law, the management of the company may be organized either into a one-tier system (board of directors) or a two-tier system (management board and supervisory board). The company shall choose the management system. The one-tier management system may be replaced by a two-tier management system and vice versa. According to the Company Law, the one-tier board of directors shall consist of at least three and not more than fifteen members. The board of directors shall appoint one or more executive members for the board of directors from among the elected members. The number of executive members shall be lower than the number of nonexecutive members of the board of directors. On the other hand, the supervisory board in the two-tier system shall have at least three but not more than eleven members (Articles 367 and 378 of the Company Law, Official Gazette of the Republic of North Macedonia, No. 28/04, 30.03.2004). According to the Company Law, there are no limitations regarding the composition of the supervisory board in terms of participation of executive and nonexecutive directors. Although the one-tier system generally makes executive and nonexecutive members to work together on the same board, while the two-tier system separates the executive directors and nonexecutive directors to serve on different boards, the Company Law allows for the supervisory board to also consist of executive directors and the management board to also consist of nonexecutive directors. Moreover, we may notice this in practice, as supervisory boards in Macedonian joint-stock companies often consist of executive directors. On the other hand, if we follow the general rule that a supervisory board does not consist of executive directors, then it could be assumed that these boards should be smaller than one-tier boards of directors, which consist of both executive and nonexecutive directors.

The only limitation regarding the board composition in North Macedonia is related to independent directors, as - according to the Company Law - if the board of directors/supervisory board has up to four nonexecutive members, at least one of the nonexecutive members of the board of directors/supervisory board shall be an independent member; or, if the board of directors/supervisory board has more than four nonexecutive members, at least one-quarter of them shall be independent members of the board of directors/supervisory board.

The system of corporate governance as one-tier and two-tier corporate board structure is imposed from the above as a contextual specific variable that can affect the corporate board characteristics, size, and composition; consequently, the corporate board's independence. In this context, we analyze the size, independence, and gender diversity by comparing corporate boards from both systems. 


\section{Shareholder Capital Concentration}

The extensive use of employee and management buyout methods of privatization in North Macedonia led to the creation of insider-dominated firms, in which there often was no place for outside directors on boards. Employees and managers participate in the ownership of shares with more than 75\% of privatized companies (Koevski, 2005). Moreover, around $82.5 \%$ of joint-stock companies have minority shareholders who own less than $10 \%$ of the total number of shares (Suklev and Sukleva, 2012). Besides, the weak legal framework for the protection of minority shareholder rights, along with the abuse of the proxy voting device (Koevski, 2001) and undeveloped capital markets, created an environment in which it is difficult to establish effective control of managerial activities. As in other transition economies, the concentration of the control in the hands of the management team, and the lack of adequate monitoring resulted in poor corporate governance (Filatotchev et al., 2003). Bearing in mind the high concentration of capital in joint-stock companies in the Republic of North Macedonia, mainly managed by direct participation of major shareholders in corporate boards, shareholder capital concentration emerges as the possible predictor of corporate board characteristics, as to the primary contextual specific variable for investigation. Thereby, it is probable that this high capital concentration should lead to smaller and less independent boards to limit their corporate governance control mechanisms.

\section{Stock Exchange Listing}

Another very specific issue in the case of the Republic of North Macedonia is the fact that, until the adoption of the new Law on Mandatory Listing on the Macedonian stock exchange, a large number of joint-stock companies were not obligated to be listed on the stock exchange. Instead, they were companies with special reporting obligations, unlisted on the official market; although they had to be listed as they meet all special conditions for listing on the official market of the stock exchange.

This had put the listed and unlisted companies in different positions in terms of transparency, accountability, and particularly in respecting the rules and requirements of trading on the Macedonian Stock Exchange and the Law of Securities. Thus, every listed company must without delay publish price-sensitive information related to their operations, and particularly those related to corporate board structures, such as information about their corporate board structures. Since the sample includes joint-stock companies - both listed and unlisted on the stock exchange - and the data of this research were collected during the period before the adoption of the new Law on Mandatory Listing on the Macedonian Stock Exchange when a large number of joint-stock companies were not obligated to be listed on the stock exchange, this situation is an opportunity to investigate the effect of stock exchange listing on corporate board struc- 
tures' characteristics. In practice, it might be investigated and verified if the stock exchange listing had pressed companies to structure their corporate boards differently in terms of their size, independence, and diversity.

Since we investigate factors related to a specific national setting, and most of them have not been previously examined in the literature or have been partially examined in a few articles, our study is exploratory. Hence, we do not formulate and test precise hypotheses. Instead, we ask two research questions that stem from the above discussion: Do firm characteristics related to corporate governance mechanisms and specific contextual factors affect board structure characteristics (size, independence, and gender diversity)? How much of the variation in board structure characteristics (size, independence, and gender diversity) is explained by firm characteristics related to corporate governance mechanisms and specific contextual factors? Figure 1 presents the model on which the study is based and which should serve as a concept for answering the research questions. The study employs a separate measurement instrument for each of the variables, explained in the research methodology section in detail.

Figure 1. Research model

\section{Control variables}

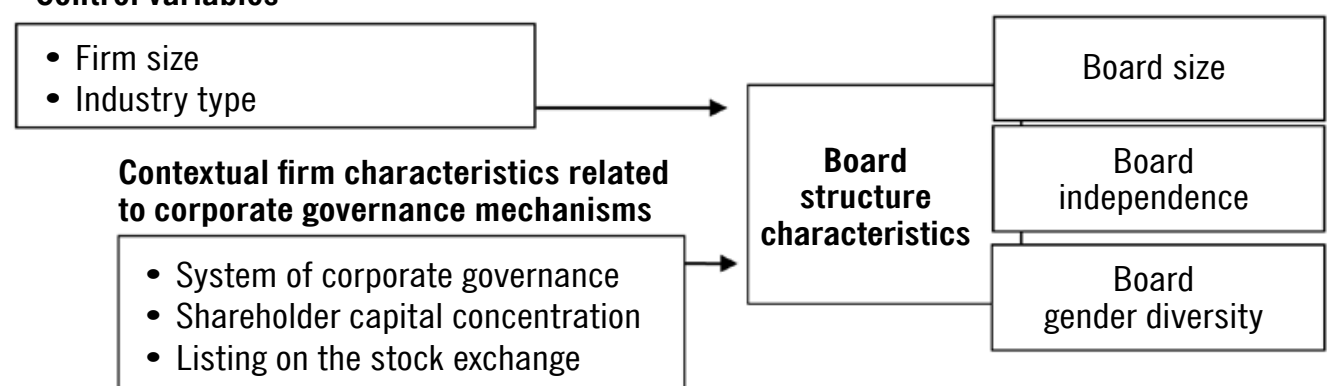

Source: own elaboration.

\section{Research methodology}

\section{Analytical Approach: The Statistical Method}

We ran a hierarchical linear regression of board characteristics on common demographic firm characteristics (firm size and industry type) as control variables and contextual firm characteristics related to corporate governance mechanisms (the system of corporate governance, shareholder capital concentration, and stock exchange 
listing) as independent variables. Using hierarchical linear regression allowed us to control for the effects of covariates on results and take into account the possible causal effects of independent variables when predicting a dependent variable.

\section{The Sample}

The sample of this study consists of large Macedonian joint-stock companies. We selected them because large joint-stock companies represent the dominant number of companies listed on the Macedonian Stock Exchange. Hence, we selected large joint-stock companies for greater comparability with those that are unlisted on the Macedonian Stock Exchange. The total number of large joint-stock companies in Macedonia is 151. Out of this number, 28 banks and other financial institutions were excluded, because they are subject to a special Law on Banks, which consists of different legislative acts that regulate their corporate governance.

Table 1. Demographic characteristics of the sample

\begin{tabular}{|l|r|r|}
\hline \multicolumn{1}{|c|}{ Companies' characteristics } & Number (N=51) & Percentage \\
\hline \begin{tabular}{|l|r|}
\hline Firm size \\
Small size of large companies
\end{tabular} & 7 & 13.7 \\
\hline $\begin{array}{l}\text { Medium size of large companies } \\
\text { Big size of large companies }\end{array}$ & 19 & 37.2 \\
\hline \begin{tabular}{l|l|} 
Industry type \\
Manufacturing
\end{tabular} & 25 & 49.1 \\
\hline Trade & 34 & 66.7 \\
\hline Services & 3 & 5.9 \\
\hline Construction & 9 & 17.6 \\
\hline Governance model & 5 & 9.8 \\
\hline One-tier system & & \\
\hline Two-tier system & 26 & 51.0 \\
\hline Listing on the Stock Exchange & 25 & 49.0 \\
\hline Joint-stock company listed on the Stock Exchange & & \\
\hline Joint-stock company not listed on the Stock Exchange & 28 & 54.9 \\
\hline Shareholder capital concentration & 23 & 45.1 \\
\hline 5\%-50\% & & \\
\hline 51\%-80\% & 15 & 29.4 \\
\hline More than 80\% & 17 & 33.3 \\
\hline
\end{tabular}

Source: own elaboration.

Furthermore, 15 public companies were excluded from the sample due to the specific conditions for corporate governance in these companies. Hence, a total of 91 companies 
were identified to be appropriate for this study. Out of this number, 51 joint-stock companies agreed to participate in the survey, representing 55.5\% response rate. The sample includes joint-stock companies with a one-tier and two-tier governance system, both listed and unlisted on the stock exchange, from various industries and of different company size (see Table 1).

\section{Data Collection}

The questionnaire was distributed to respondents from the entire territory of the Republic of North Macedonia in two ways: via electronic mail or delivered in printed form. A total of 91 questionnaires were distributed from October 2013 to January 2014. The survey was distributed only to top and middle-level managers. Additional information, especially regarding the ownership structure of joint-stock companies, was received from the Central Securities Depository of the Republic of North Macedonia.

Even though the data was collected in this period, the findings from the research are relevant and significant, bearing in mind that two out of three contextual factors specific for the Republic of North Macedonia - the model of corporate governance and shareholder capital concentration - were substantial characteristics of Macedonian joint-stock companies and the institutional environment related to corporate governance. Regarding the third studied determinant of the structuring of corporate boards - listing on the stock exchange - according to the new Law on Mandatory Listing on the Macedonian Stock Exchange, all joint-stock companies are obligated to be listed on the stock exchange, unlike in the previous situation. Hence, this situation is an opportunity to investigate the effect of stock exchange listing on the corporate boards structuring characteristics.

\section{Variable Operationalization}

Board size is defined as the number of directors in the one-tier board of directors and two-tier supervisory board. Board independence is defined as the number of independent directors in the one-tier board of directors and two-tier supervisory board according to the definition of independent directors in the Company Law of the Republic of North Macedonia. A board's gender diversity is measured by the number of women in the one-tier board of directors and two-tier supervisory board. For the industry type, i.e. the sector in which companies operate, only one dummy variable is created. Since companies from non-manufacturing industry (trade, services, and construction) do not suffice to create separate groups, we merge these industries into one group, so the companies are divided into two groups: joint-stock companies in the manufacturing 
industry and joint-stock companies in other industries (trade, services, and construction). For firm size, we created an ordinal variable and divided the companies into three groups according to the number of employees: small, medium, and large joint-stock companies.

For the system of corporate governance, a dummy variable is created, while joint-stock companies are divided into joint-stock companies with a one-tier system and joint-stock companies with a two-tier system. Depending on whether joint-stock companies are listed on the stock exchange, we introduce a dummy variable and divide companies into listed and unlisted on the stock exchange. For shareholder capital concentration, we establish an ordinal variable and divide companies into three groups: group 1 (capital concentration up to 50\%); group 2 (capital concentration of 51\%-80\%); and group 3 (capital concentration of $81 \%$ or more of the shareholder capital). This categorization is based on the levels of capital concentration and, accordingly, the type of corporate control, which consists of four levels: absolute control (the largest shareholders control $81 \%$ or more of the shareholder capital), majority control (the largest shareholders control 51\%-80\% of the shareholder capital), minority control (the largest shareholders control $5-50 \%$ of the shareholder capital), and management control (the largest shareholders control less than $5 \%$ of the shareholder capital; Gorriz and Fumas, 1996). We made a small modification of this classification, as we merged the management control level and the minority control level into a single group 1 (capital concentration up to $50 \%$, to create a larger and more representative group.

\section{Results and analysis}

\section{Board Size}

According to the data from the joint-stock companies under scrutiny, we note that the joint-stock companies with a one-tier governance model have the average number of board members at 5.6. Meanwhile, the largest board consists of nine and the smallest of three members. In joint-stock companies with a two-tier governance model, the average number of supervisory board members amounts to 4.1 members. However, we should indicate that most supervisory boards have three members, while only one joint-stock company has a supervisory board that consists of a significantly larger number of members (11), while the average number of management board members is 5.2 members; the largest management board has 10 and the smallest three members. Some descriptive statistics of the distribution of researched variables to board size is presented in Table 2. 
Table 2. Descriptive statistics of the distribution of researched variables to board size

\begin{tabular}{|l|l|l|}
\hline \multicolumn{1}{|c|}{ Variable } & Mean & Std. Dev. \\
\hline \begin{tabular}{|l|l|}
\hline Governance system \\
One-tier system \\
Two-tier system
\end{tabular} & 5.62 & 1.675 \\
\hline $\begin{array}{l}\text { Listing on the Stock Exchange } \\
\text { Joint stock company listed on the Stock Exchange }\end{array}$ & 3.80 & \\
\hline Joint stock company not listed on the Stock Exchange & & 1.900 \\
\hline Shareholder capital concentration & 5.07 \\
\hline 5\%-50\% & 4.41 & 1.221 \\
\hline 51\%-80\% & & \\
\hline More than 80\% & 4.67 & 1.234 \\
\hline Firm size & 4.88 & 2.147 \\
\hline Small size of large companies & 4.78 & 1.353 \\
\hline $\begin{array}{l}\text { Medium size of large companies } \\
\text { Big size of large companies }\end{array}$ & & \\
\hline Industry type & 4.57 & 1.397 \\
\hline $\begin{array}{l}\text { Manufacturing } \\
\text { Others }\end{array}$ & 4.47 & 1.389 \\
\hline
\end{tabular}

Source: own elaboration.

From the data in Table 2, we may notice that the companies with a one-tier governance system have larger corporate boards - on average 5.62 members - than companies with a two-tier governance system, which average 4.41 members. Then, the joint-stock companies listed on the stock exchange have larger boards with the average of $5.07 \mathrm{mem}$ bers than the joint-stock companies unlisted on the stock exchange, with on average 4.41 members. We notice larger corporate boards at companies with capital concentration category $51 \%-80 \%$ (group 2), compared to the other two groups of capital concentration. Moreover, larger companies and those from the manufacturing industry have a larger board than other categories of companies.

As explained above and based on the proposed research model, we ran hierarchical linear regression of board characteristics on common demographic firm characteristics (firm size and industry type) as control variables and contextual firm characteristics related to corporate governance mechanisms (the system of corporate governance, shareholder capital concentration, and stock exchange listing) as independent variables.

Table 3 reports the estimates of parameters in which the dependent variable is the board size. The assumptions of linearity, the independence of errors, homoscedasticity, unu- 
sual points, and the normality of residuals were met. The assumption of the non-existence of multicollinearity is also met, while all the tolerance values are higher than 0.1.

Table 3. Hierarchical multiple regression of boards size

\begin{tabular}{|c|c|c|c|c|c|}
\hline \multirow{2}{*}{ Model } & \multicolumn{2}{|c|}{$\begin{array}{l}\text { Unstandardized } \\
\text { Coefficients }\end{array}$} & \multirow{2}{*}{$\begin{array}{c}\text { Standardized } \\
\text { Coefficients } \\
\text { Beta }\end{array}$} & \multirow{2}{*}{$t$} & \multirow{2}{*}{ Sig. } \\
\hline & B & Std. Error & & & \\
\hline \multirow{3}{*}{$\begin{array}{l}1 \text { (Constant) } \\
\text { Industry type } \\
\text { Company size }\end{array}$} & 3.971 & .801 & & 4.956 & .000 \\
\hline & -.006 & .510 & -.002 & -.011 & .991 \\
\hline & .348 & .335 & .155 & 1.037 & .305 \\
\hline \multirow{6}{*}{$\begin{array}{l}2 \text { (Constant) } \\
\text { Industry type } \\
\text { Firm size } \\
\text { Stock exchange listing } \\
\text { Shareholder capital concentration } \\
\text { Corporate governance system }\end{array}$} & 4.476 & .798 & & 5.612 & .000 \\
\hline & -.054 & .453 & -.016 & -.120 & .905 \\
\hline & .633 & .296 & .283 & 2.138 & .038 \\
\hline & .282 & .419 & .088 & .675 & .503 \\
\hline & -.171 & .276 & -.087 & -.619 & .539 \\
\hline & -1.974 & .396 & -.620 & -4.980 & .000 \\
\hline
\end{tabular}

Source: authors' analysis.

Model 1 shows results for a regression of the board size on two control variables: industry type and company size. We find that these two demographic companies' characteristics have no effect or explanatory power on variation in board size (the adjusted $\mathrm{R}^{2}$ of model 1 is -0.018 ), while the F-statistics (0.576) of this model is statistically insignificant.

Model 2 shows results for the regression of board size in the three main researched variables: stock exchange listing, shareholder capital concentration, and the system of corporate governance. Model 2 explains a sizeable part of the variation in board size, with an adjusted $\mathrm{R}^{2}$ of 0.329 . The F-statistics (5.812) of this model is statistically significant. According to the values of B coefficient, company size and governance system have a statistically significant influence on board size. If the level of company size increases by 1 , the board size will increase by 0.633 . Moreover, if the governance model shifts from one-tier to two tier-model, the board size will decrease by 1.974 . This means that larger companies with the one-tier model have statistically significant larger corporate boards. Moreover, we should add that since the company size has a statistically significant effect on board size only in model 2 it means that there is 
a difference among company size in their board size only in companies grouped according to the governance system.

\section{Board Composition (Independence)}

Regarding the board of directors' composition in large joint-stock companies in the Republic of North Macedonia, the average number of executive directors amounts to 1.5 members. According to empirical data, the maximum number of executive directors is three. Boards of directors have four nonexecutive directors on average. The largest board has seven nonexecutive directors. The nonexecutive directors represent $71.2 \%$ of the total number of board members. On the other hand, the share of independent members in the total number of nonexecutive members is $43.3 \%$, while the percentage of independent directors in the total number of members is $30.8 \%$.

Some descriptive statistics of the distribution of researched variables to the number of independent directors is presented in Table 4.

Table 4. Descriptive statistics of the distribution of researched variables to the number of independent directors

\section{Variable}

\section{Governance system}

One-tier system

Two-tier system

\section{Listing on the Stock Exchange}

Joint-stock company listed on the Stock Exchange

Joint-stock company not listed on the Stock Exchange

\section{Shareholder capital concentration}

$5 \%-50 \%$

$51 \%-80 \%$

More than $80 \%$

\section{Firm size}

Small size of large companies

Medium size of large companies

Big size of large companies

\section{Industry type}

Manufacturing

Others
Mean

Std. Dev.

Source: authors' analysis.

1.29

1.26

0.756

1.79

0.733

1.587

1.65

1.412

1.25
0.683

The data in Table 4 reveals that companies with a one-tier governance system have a larger number of independent directors (on average 1.88) than companies with a two- 
tier governance system, which have an average of 1.13 directors. Moreover, joint-stock companies listed on the stock exchange have on average a larger number of independent directors with, on average, 1.64 directors than the joint-stock companies unlisted on the stock exchange with, on average, 1.36 directors. As in the case of total board size, a larger number of independent directors can be noticed in companies with capital concentration category $51 \%-80 \%$ (group 2) compared to the other two groups of capital concentration. Moreover, larger companies and those from the manufacturing sector have a larger number of independent directors than other categories of companies, according to company size and industry type criteria.

Table 5 reports the estimates for regressions in which the dependent variable is the number of independent directors on the board. The assumptions of linearity, the independence of errors, homoscedasticity, unusual points, and the normality of residuals were met. The assumption of the non-existence of multicollinearity is also met, while all the tolerance values are higher than 0.1.

Table 5. Hierarchical multiple regression of the number of independent directors

\begin{tabular}{|c|c|c|c|c|c|}
\hline \multirow{2}{*}{ Model } & \multicolumn{2}{|c|}{$\begin{array}{l}\text { Unstandardized } \\
\text { Coefficients }\end{array}$} & \multirow{2}{*}{$\begin{array}{c}\text { Standardized } \\
\text { Coefficients } \\
\text { Beta }\end{array}$} & \multirow{2}{*}{$t$} & \multirow{2}{*}{ Sig. } \\
\hline & B & Std. Error & & & \\
\hline \multirow{3}{*}{$\begin{array}{l}1 \text { (Constant) } \\
\text { Industry type } \\
\text { Company size }\end{array}$} & .686 & .607 & & 1.130 & .264 \\
\hline & .286 & .387 & .109 & .738 & .464 \\
\hline & .273 & .254 & .159 & 1.076 & .288 \\
\hline \multirow{6}{*}{$\begin{array}{l}2 \text { (Constant) } \\
\text { Industry type } \\
\text { Firm size } \\
\text { Stock exchange listing } \\
\text { Shareholder capital concentration } \\
\text { Corporate governance system }\end{array}$} & 1.178 & .710 & & 1.659 & .104 \\
\hline & .356 & .404 & .136 & .880 & .383 \\
\hline & .446 & .264 & .260 & 1.692 & .098 \\
\hline & -.022 & .373 & -.009 & -.060 & .953 \\
\hline & -.231 & .246 & -.153 & -.938 & .354 \\
\hline & -.952 & .353 & -.390 & -2.697 & .010 \\
\hline
\end{tabular}

Source: authors' analysis.

Model 1 shows results for a regression in the number of independent directors on two control variables: industry type and company size. We find that these two demographic companies' characteristics have no effect or explanatory power on variation in the 
number of independent directors (the adjusted $\mathrm{R}^{2}$ of model 1 is 0.006), while F-statistics (1.146) of this model is statistically insignificant.

Model 2 shows results for a regression of the number of independent directors on the main three companies' characteristics: stock exchange listing, shareholder capital concentration, and the system of corporate governance. Model 2 explains the larger proportion of the variation in the number of independent directors than the model 1, with an adjusted $\mathrm{R}^{2}$ of 0.096 , yet it is considerably lower than in the case of the board size. The F-statistics (2.032) of this model is statistically significant (0.091)

According to the values of the B coefficient, the regression on board size, company size, and governance system have a statistically significant influence on the number of independent directors. This means that if the level of company size increases by 1 , the number of independent directors will increase by 0.446 . Moreover, if the governance model shifts from one-tier to tier-model, the board size will decrease by 0.952 . This means that larger companies with the one-tier model have a statistically significant larger number of independent directors. Moreover, we must add that since the company size has a statistically significant effect on the number of independent directors only in model 2, it means that there is a difference among companies with different size in their number of independent directors only in the companies grouped according to the governance system.

\section{Board Gender Diversity}

We may conclude about gender diversity of top management in large joint-companies that the majority (or 88\%) of companies under scrutiny have not a single woman in the rank of chief executive officer, i.e. only $12 \%$ have one woman in this role. Regarding the gender structure of corporate boards, in the majority of joint-stock companies with a one-tier governance model, women represent less than $20 \%$ of nonexecutive directors. The maximum number of women as nonexecutive directors on boards is three, while $46 \%$ of boards do not have even a single woman in the composition of nonexecutive directors. In the case of joint-stock companies with a two-tier governance model in $20 \%$ of the management boards, the number of women is zero, while $36 \%$ of management boards have only one woman in their composition. A curious case is one management board, i.e. $4 \%$ of the management boards, which consists of five women. The gender structure of the supervisory board members shows that the majority of boards have only one woman in their composition (44\%); $20 \%$ of boards have two women, while $36 \%$ do not have any women in their structure. 
Some descriptive statistics of the distribution of researched variables to board size is presented in Table 6.

Table 6. Descriptive statistics of the distribution of researched variables to the number of women directors

\begin{tabular}{|c|c|c|}
\hline Variable & Mean & Std. Dev. \\
\hline $\begin{array}{l}\text { Governance system } \\
\text { One-tier system } \\
\text { Two-tier system }\end{array}$ & $\begin{array}{l}1.04 \\
0.79\end{array}$ & $\begin{array}{l}1.248 \\
0.721\end{array}$ \\
\hline $\begin{array}{l}\text { Listing on the Stock Exchange } \\
\text { Joint-stock company listed on the Stock Exchange } \\
\text { Joint-stock company not listed on the Stock Exchange }\end{array}$ & $\begin{array}{l}0.86 \\
1\end{array}$ & $\begin{array}{l}1.008 \\
1.069\end{array}$ \\
\hline $\begin{array}{l}\text { Shareholder capital concentration } \\
5 \%-50 \% \\
51 \%-80 \% \\
\text { More than } 80 \%\end{array}$ & $\begin{array}{l}0.87 \\
1.29 \\
0.61\end{array}$ & $\begin{array}{l}1.187 \\
0.985 \\
0.850\end{array}$ \\
\hline $\begin{array}{l}\text { Firm size } \\
\text { Small size of large companies } \\
\text { Medium size of large companies } \\
\text { Big size of large companies }\end{array}$ & $\begin{array}{l}1.29 \\
1 \\
0.75\end{array}$ & $\begin{array}{l}1.380 \\
1.054 \\
0.897\end{array}$ \\
\hline $\begin{array}{l}\text { Industry type } \\
\text { Manufacturing } \\
\text { Others }\end{array}$ & $\begin{array}{l}0.79 \\
1.19\end{array}$ & $\begin{array}{l}0.914 \\
1.223\end{array}$ \\
\hline
\end{tabular}

Source: own elaboration.

The data in Table 6 shows different tendencies in some categories of companies than the cases of total board size and number of independent directors. Unlike the joint-stock companies listed on the stock exchange, large companies, and companies from the manufacturing industry, which have larger total board size and a larger number of independent directors, these companies on average have a smaller number of women directors in their boards. Still, as in the case of the board size and the number of independent directors, companies with one-tier boards and with the capital concentration of 51-80\% on average have a larger number of women directors compared to companies with two-tier boards with a capital concentration lower and higher than 51-80\%.

Although hierarchical multiple regression was conducted to identify determinants of proportion of women on boards of directors, the results of this model are not presented in this section, since we found no significant model (no one model passed the statistic 
diagnostics, i.e. no one model is a significant fit for the data). Hence, we did not succeed in finding any predictor of the presence of women on corporate boards.

\section{Discussion}

Compared to foreign joint-stock companies, Macedonian joint-stock companies still lag in several areas and require improvements in the corporate governance structures and functioning.

First, joint-stock companies have relatively small boards, which do not provide positive effects from the participation of a larger number of board members, both insiders and outsiders, who would bring more knowledge and expertise.

According to the data from the joint-stock companies under scrutiny, we may summarize that the average number of board members in the joint-stock companies with a one-tier governance model is 5.6 members, while the average number of supervisory board members in joint-stock companies with a two-tier governance model amounts to $4.1 \mathrm{mem}$ bers. A study that investigated the size of boards of directors in three countries in the region, Serbia, Bosnia and Herzegovina, and the Republic of North Macedonia, showed similar results. It indicates that joint-stock companies in these countries have relatively small boards, with certain variations between countries, with an average number from 4.1 in Bosnia and Herzegovina to 6.8 members in the Republic of North Macedonia (Djulic and Kuzman, 2013). The 2010 research of 184 joint-stock companies with a two-tier governance model in Croatia shows relatively small management boards, in which the average number of supervisory boards' members is 5.1 (Rončević et al., 2011). However, these numbers are far behind the good corporate governance practices in developed countries. Summarized data from various studies conducted in American corporations in the 1990s and during the 2000s shows that the average number of directors on boards ranges from 9.5 to 10 members (Denis and Sarin, 1999; Gillan et al., 2004; Boone et al., 2007; Ning et al., 2007). Furthermore, the Spencer Stuart Board Index 2013 documents larger boards of directors in developed countries, with the average size of 10 members in the USA, 11 in the UK, 14 in France, and up to 15 in Germany.

Smaller corporate boards in Macedonian companies may be explained by the determinants that could affect board size. Our study proves the influence of company size and corporate governance system on board size. This means that larger companies with a one-tier model have statistically significant larger corporate boards. The result regard- 
ing the company size was expected, and it finds support in the literature. Hermalin and Weisbach (1998) argue that board size is likely to increase with firms' scale and complexity, measured by firm size, age, and the number of its business segments. The result regarding the corporate governance system was also expected, bearing in mind the regulation and practice in the Republic of North Macedonia. For instance, even though the Company Law does not set any limitations regarding the composition of the supervisory board in terms of participation of executive and nonexecutive directors, the practice of joint-stock companies in North Macedonia still reveals that their supervisory boards typically consist of nonexecutive directors. Hence, the absence of executive directors from supervisory boards makes these boards smaller than the one-tier boards of directors, which - according to the Company Law - must have a mix of executive and nonexecutive directors. Furthermore, though this study did not prove this, we must still emphasize that we expect the small size of the board of directors due to the process of Macedonia's privatization program, mostly realized through management buyouts, which resulted in strong managers' control and bargaining power in Macedonian joint-stock companies and their incentives for smaller corporate boards with lower control role.

Second, having in mind the small total number of board members, the number of outside independent nonexecutive members is also small and insufficient for them to input greater objectivity, independence, and quality to their respective boards. According to the data from the joint-stock companies under scrutiny, we infer that the absolute number of nonexecutive directors is still small, four nonexecutive directors on average, despite the high relative share $(71.2 \%)$ of nonexecutive directors in the total number of one-tier boards. The number of independent nonexecutive members is also small, as is the share of independent directors in the total number of directors (30.8\%). The outside member dominance in relation to inside board members is not characteristic for two-tier boards, in which inside members prevail as - according to Company Law - there are no limitations regarding the composition of a supervisory board in terms of the predominance of nonexecutive directors over executive directors.

Similar results to our study were obtained in a study conducted in Croatia in 2011, in which the share of independent members on boards amounted to $38.7 \%$, although the authors suggest that this number is significantly lower in reality (Tipuric and Simac, 2012). A study conducted in the Federation of Bosnia and Herzegovina shows that in more than $50 \%$ of the analyzed companies the supervisory board consists of only three members, while only $11 \%$ of board company members are independent and $38 \%$ members are either stockholders or company employees (SEE Business Solutions, 2011). 
The relative share of independent nonexecutive directors in the total number of board directors in corporate practice in developed countries - shows a significantly higher proportion. According to Bone et al. (2007), the increase in board size primarily reflects the addition of outside independent board members, whose percentage steadily grows until it reaches $69 \%$ by year 10 after the IPO. Gillan et al. (2004) report that the mean proportion of independent outsiders in their sample of large firms in the 1997-2000 period is 59\%. Ning et al. (2007) find that the percentage of insiders on the board steadily decreases from $30.4 \%$ in 1988 to $24.36 \%$ in 1999 , while independent directors steadily increase from $59.20 \%$ to $67.17 \%$.

The smaller number of independent directors on corporate boards in Macedonian companies might be explained by the same determinants that explain board size. Our study managed to prove the influence of company size and corporate governance system on the number of independent directors. This means that larger companies with the one-tier model have a statistically significant larger number of independent directors. Although, the study did not prove the influence of stock exchange listing and capital concentration as determinants that predict the number of independent directors. However, bearing in mind the small relative proportion of independent directors compared to companies in developed countries, we believe that these are important situational factors. Regarding the influence of capital concentration, it is probable that high capital concentration accompanied by strong managers' control and bargaining power should lead to smaller and less independent boards and to limit their corporate governance control mechanisms. Regarding the influence of stock exchange listing, it is also probable that the large number of joint-stock companies that were not obligated to be listed on the stock exchange - though they had to be listed - put them in a comfortable position of structuring corporate boards with less transparency and responsibility, unlike the companies listed on the stock exchange. This situation has created smaller and corporate boards with a lower proportion of independent directors.

Regarding gender diversity, we infer that they represent less than $20 \%$ of directors in both one-tier and two-tier boards. Studies from Serbia, Bosnia and Herzegovina, and the Republic of North Macedonia show similar results with our study. These studies indicate that joint-stock companies in these countries have a small average number of women on boards of directors, which varies from 1.2 to 1.5 women per board, with small variations between countries, whereby specifically in the Republic of North Macedonia, the relative share of women on boards of directors amounts to $17.2 \%$ (Djulic and Kuzman, 2013). Research conducted in Croatia on a sample of 132 jointstock companies shows a low share of $20 \%$ of women on corporate boards (Tipuric and Simac, 2012). 
The study of women on corporate boards of joint-stock companies in developed economies shows that - out of the total number of board of directors' members in joint-stock companies - the proportion of women members amounted to $16.1 \%$ in the 2011 Fortune 500, and to $12.5 \%$ in the FTSE 100. In 27 EU member-countries, the relative participation of women on boards of the largest joint-stock companies listed on stock exchanges amounts to $15.8 \%$ of the total number of board members, i.e., $16.8 \%$ of nonexecutive board members (Women on boards - Factsheet 2, 2012).

This is an area that requires improvement globally. Likewise, Macedonian joint-stock companies need to follow positive world trends and activities undertaken in the direction of increasing the number of women on boards, so as to engender the positive effects of the participation of women in management and corporate boards on operation performance. McKinsey \& Company determine that a higher level of gender diversity on top management positions brings a higher level of organizational effectiveness, higher rates of return on capital, an improvement of other operational results, and a significant increase of shares prices than in average realizations in respective sectors of joint-stock companies.

We did not succeed in finding any predictor of the presence of women on corporate boards. Still, the authorities should consider the possible measures for implementing low limits for the equitable representation of women on corporate boards in the Company Law or codes for good corporate governance practice.

\section{Conclusion}

Our study leads to the conclusion that the best corporate governance practices worldwide must be used as a starting basis for future improvements of corporate governance in joint-stock companies in developing countries that experienced transition processes. Compared to their foreign counterparts, Macedonian joint-stock companies still lag in several areas and require improvements of corporate governance structure and functioning. First, joint-stock companies have relatively small boards, which do not provide positive effects from the participation of a larger number of board members - both inside and outside - who would bring more knowledge and expertise. Second, having in mind the small total number of board members, the number of nonexecutive outside independent members is also small and insufficient for them to input greater objectivity, independence, and quality to the boards in which they are members. Having in mind the high concentration of capital in joint-stock companies, the influence of nonexecutive outside independent directors is even more limited. Third, although the numbers 
regarding the participation of women on boards are low both around the world and in the region, joint-stock companies should follow the positive world trends and activities that are undertaken in the hope of increasing the number of women on boards, having in mind the positive effects of the participation of women in management and corporate boards on operation performance.

This article gives a reasonable basis for further empirical study and comparative analysis of the results and knowledge from other developing countries. Considering that similar results and insights were obtained from other studies on the practice of corporate governance in the region of Southeast Europe, we recommend that these countries learn from each other the best practices of corporate governance and harmonizing their practices with those of developed countries so as to jointly advance the region's economy.

\section{Limitations and Further Research}

The limitation of our study is related to the fact that until adoption of the new Law on Mandatory Listing of Joint-Stock Companies on the Macedonian Stock Exchange a large number of joint-stock companies were not obligated to make their financial statements public due to which it was difficult to obtain information on their financial performance. In turn, this Law made it difficult to conduct various investigations of companies' everyday operations in their operational performance. Thus, the focus of future research should be the relation between the various characteristics of corporate governance and joint-stock companies' performance.

\section{References}

Ahmadi, A., Nakaa, N., and Bouri, A. (2018). Chief Executive Officer attributes, board structures, gender diversity and firm performance among French CAC 40 listed firms. Research in International Business and Finance, 44, 218-226. https://doi.org/10.1016/j.ribaf.2017.07.083.

Alqatan, A., Chbib, I., and Hussainey, K. (2019). How does board structure impact on firm performance in the UK? Corporate Board: Role, Duties \& Composition, 15(2), 18-27. https://doi.org/10.22495/cbv15i2art2.

Boone, A.L., Field, L.C., Karpoff, J.M., and Raheja, C.G. (2007). The determinants of corporate board size and composition: An empirical analysis. Journal of Financial Economics, 85(1), 66-101. https://doi.org/10.1016/j.jfineco.2006.05.004.

Cadbury, A. (1992). Report of the Committee on the Financial Aspects of the Corporate Governance. London: Gee and Co. Ltd.

Carter, D.A., Simkins B.J., and Simpson, W.G. (2003). Corporate Governance, Board Diversity and Firm Value. The Financial Review, 38, 33-53. https://doi.org/10.1111/1540-6288.00034.

Central Securities Depository (2012). Skopje. 
Chau, G. and Gray, S. (2010). Family ownership, board independence and voluntary disclosure: Evidence from Hong Kong. Journal of International Accounting, Auditing and Taxation, 19(2), 93-109. https://doi.org/10.1016/j.intaccaudtax.2010.07.002.

Coles, J.L., Daniel, N.D., and Naveen, L. (2008). Boards: Does one size fit all? Journal of Financial Economics, 87(2), 329-356. https://doi.org/10.1016/j.jfineco.2006.08.008.

Company Law (1996). Official Gazette of the Republic of North Macedonia, 28/96.

Company Law (2004). Official Gazette of the Republic of North Macedonia, 28/04.

Daily, C.M., Dalton, D.R., and Cannella, A.A. (2003). Introduction to special topic forum corporate governance: Decades of dialogue and data. Academy of Management Review, 28(3), 371-382. https://doi.org/10.5465/amr.2003.10196703.

Dalton, D., Daily, C., Johnson, J., and Ellstrand, A. (1999). Number of directors and financial performance: A meta-analysis. Academy of Management Journal, 42(6), 674-686. https://doi.org/10.2307/256988.

Denis, D. and Sarin, A. (1999). Ownership and board structure in publicly traded corporations. Journal of Financial Economics, 52(2), 187-223. https://doi.org/10.1016/S0304-405X(99)00008-2.

Denis, D.K. and McConnell, J.J. (2003). International corporate governance. Journal of Financial and Quantitative Analysis, 38(1), 1-36. https://doi.org/10.2307/4126762.

Dibra, R., Brahimi, F., Shehu, H., and Suli, D. (2013). Corporate governance in transition economies: The case of different countries in the field of corporate governance. European Journal of Business and Management, 5(18), 101-108.

Djulic, K. and Kuzman, T. (2013). Women on Corporate Boards in Bosnia and Herzegovina. FYR Macedonia and Serbia, Washington: IFC. https://doi.org/10.1596/26119.

Ertimura, Y., Ferrib, F., and Stubbenc, S. (2010). Board of directors' responsiveness to shareholders: Evidence from shareholder proposals. Journal of Corporate Finance, 16(1), 53-72. https://doi.org/10.1016/j.jcorpfin.2009.07.005.

Ferreira, D. and Kirchmaier, T. (2013). Corporate boards in Europe: size, independence and gender diversity. In: M. Belcredi and G. Ferrarini (eds.), Boards and Shareholders in European Listed Companies: Facts, Context and Post-Crisis Reforms. Cambridge: Cambridge University Press. https://doi.org/10.1017/CBO9781139629126.004.

Filatotchev, I., Wright, M., Uhlenbruck, M., Tihayi, L., and Hoskisson, R.E. (2003). Governance, organizational capabilities, and restructuring in transition economies. Journal of World Business, 38(4), 331-347. https://doi.org/10.1016/j.jwb.2003.08.019.

Financial Reporting Council (2016). The UK Corporate Governance Code. London: The Financial Reporting Council Limited.

Gillan, S., Hartzell, J., and Starks, L. (2004). Explaining corporate governance: Boards, bylaws, and charter provisions, unpublished working paper. University of Texas.

https://doi.org/10.2139/ssrn.442740.

Goodstein, J., Gautam, K., and Boeker, W. (1994). The effects of board size and diversity on strategic change. Strategic Management Journal, 15(3), 241-250. https://doi.org/10.1002/smj.4250150305.

Guest, P. (2008). The determinants of board size and composition: Evidence from the UK. Journal of Corporate Finance, 14(1), 51-72. https://doi.org/10.1016/j.jcorpfin.2008.01.002.

Hermalin, B.E. and Weisbach, M.S. (2003). Board of directors as an endogenously determined institution: A survey of the economic literature. Federal Reserve Bank of New York Economic Policy Review, 9(1), 1-20.

Jensen, M. (1993). The modern industrial revolution, exit, and the failure of internal control systems. Journal of Finance, 48(3), 831-880. https://doi.org/10.1111/j.1540-6261.1993.tb04022.x. 
Kao, M.F., Hodgkinson, L., and Jaafar, A. (2019). Ownership structure, board of directors and firm performance: evidence from Taiwan. The International Journal of Business in Society, 19(1), 189-216. https://doi.org/10.1108/CG-04-2018-0144.

Koevski, G. (2001). Minority shareholder rights in the current Macedonian legislation. Review of Central and East European Law, 27(1), 41-52. https://doi.org/10.1163/157303501124667432.

Koevski, G. (2005). Comparative Corporate Governance. Skopje: Faculty of Law "Justinian the First".

Ning, Y., Davidson, N.W., and Zhong, K. (2007). The variability of board size determinants: An empirical analysis. Journal of Applied Finance, 17(2), 46-61.

OECD Principles of Corporate Governance (2004). Paris: OECD.

Paniagua, J., Rivelles, R., and Sapena, J. (2018). Corporate governance and financial performance: The role of ownership and board structure. Journal of Business Research, 89, 229-234. https://doi.org/10.1016/j.jbusres.2018.01.060.

Pearce, J. and Zahra, S. (1992). Board composition from a strategic contingency perspective. Journal of Management Studies, 29(4), 411-438. https://doi.org/10.1111/j.1467-6486.1992.tb00672.x.

Raheja, C.G. (2005). Determinants of board size and composition: A theory of corporate boards. Journal of Financial and Quantitative Analysis, 40(2), 283-306. https://doi.org/10.1017/S0022109000002313.

Rončević, A., Bulog, I., and Vignali, G. (2011). Development of corporate governance in South East Europe - Case of Croatia. In: D. Tipuric and V. Trivun (eds.), Corporate Governance in Southeast Europe: in Search for Transparency and Efficiency [Special Issue]. International Journal of Management Cases, 14(3), 90-98. https://doi.org/10.5848/APBJ.2012.00074.

SEE Business Solutions Report (2011). Sarajevo: SEE Business Solutions.

Shleifer, A. and Vishny, R. (1997). A survey of corporate governance. Journal of Finance, 52(2), 737-783. https://doi.org/10.1111/j.1540-6261.1997.tb04820.x.

Singh, V., Terjesen, S., and Vinnicombe, S. (2008). Newly appointed directors in the boardroom: How do women and men differ? European Management Journal, 26(1), 48-58.

https://doi.org/10.1016/j.emj.2007.10.002.

Spencer Stuart Board Index (2013). Chicago: Spencer Stuart.

Suklev, B. and Sukleva, M. (2012). The challenge of best practice for future corporate governance sustainability in Corporate Governance: Its Perspectives and Challenges in Dynamic and Complex Business Environment [International Conference Proceedings], 36-48. Skopje: Faculty of Economics-Skopje.

Tipuric, D. and Simac, A. (2012). Corporate governance in Croatia - Towards a good practice in Corporate Governance: Its Perspectives and Challenges in Dynamic and Complex Business Environment [International Conference Proceedings]. Skopje: Faculty of Economics-Skopje.

Tulung, J.E. and Ramdani, D. (2018). Independence, size and performance of the board: An emerging market research. Corporate Ownership \& Control, 15(2-1), 201-208. https://doi.org/10.22495/cocv15i2c1p6.

Women on boards (2012). Factsheet 2, Gender equality in the Member States. Brussels: European Commission.

World Bank (2014). http://www.ifc.org/wps/wcm/connect/topics_ext_content/ifc_external_corporate_ site corporate+governance/overview.

Yermack, D. (1996). Higher market valuation of companies with a small board of directors. Journal of Financial Economics, 40(2), 185-212. https://doi.org/10.1016/0304-405X(95)00844-5. 